\title{
Description of Populations and Lactic Dehydrogenase Activity (LDH) of Apodemus agrarius in the Ecosystems of a Town and of Cultivated Fields
}

\author{
Ludmiła WOLANSKA \& Aleksandra KUBICZ
}

\begin{abstract}
Wolanska L. \& Kubicz A., 1986: Description of populations and lactic dehydrogenase activity ( $\mathrm{LDH}$ ) of Apodemus agrarius in the ecosystems of a town and of cultivated fields. Acta theriol., 31, 1: 3-15 [With 7 Tables \& 2 Figs.]

Examination was made of age and sex structure, body weight and reproduction, and also of lactic dehydrogenase activity (LDH) in tissues of the skeletal muscles, heart, liver and kidneys of Apodemus agrarius It was found that there were more young individuals in the town park (Wrocław) and 2. living in cultivated fields outside the city boundaries. It was found that three were more young individuals in the town park and that their body weight was greater than in the suburban population. The spring predominance of males over femaels was more marked in the suburban population. LDH activity was greatest in muscles and lowest in the heart and kidneys, and in spring was significantly greater in the tissues of females than in males. No difference in LDH activity between the two study populations was shown to occur, only dependence on sex and age of the animals and the season of their capture.

[Dept. of Zool., Acad. of Agriculture, Cybulskiego 20, 50-205 Wrocław, and Inst. Biochem., Univ. of Wrocław, Tamka 2, 50-137 Wrocław, Poland]
\end{abstract}

\section{INTRODUCTION}

Urbanization processes characteristic of contemporary civilisation bring about important changes in the composition and structure of theriofauna. Many species of mammals desert highly urbanized areas, while a few remain and adapt themselves to their changed living conditions. Andrzejewski et al., (1978) showed that as urbanization proceeds it is followed by impoverishment of the rodent community, together with simultaneous increase in the domination of one species only, Apodemus agrarius. This species occurs very commonly in urban ecosystems, even in central parts of towns. The process of adaptation to urban conditions, termed by Andrzejewski et al., (1978) synurbanization, causes changes in age and sex structure, in body weight, in size and shape of skulls and also in diet (Andrzejewski et al., 1978; Babińska-Werka \& Garbarczyk, 1981; Sikorski, 1982). It would therefore appear likely that conditions for the existence of this species in towns may also cause changes 
in metabolism, which might be expressed in, inter alia, a change in the amount of some enzymes in cells.

It was therefore decided to ascertain in what way urbanization processes affected a population of $A$. agrarius in respect of its age and sex structure, body weight, reproduction and also the behaviour of lactic dehydrogenase ( $\mathrm{LDH})$ activity in the animals' organs under the conditions of the large town of Wrocław. In order to do this comparison was made of two populations: one from the centre of Wrockaw and the other, as the control, from fields outside the town limits. Investigation was made to determine to what degree $\mathrm{LDH}$ level depended on age, body weight and sexual activity of the individuals in the two populations.

\section{DESCRIPTION OF THE STUDY AREAS}

Studies were carried out from the spring of 1977 to that of 1980 and covered 3 ecosystems: 1. part of the Szczytnicki Park surrounded by the busy Kopernik, Mickiewicz and Rosenbergs streets of Wroclaw, 2. the St. Lawrence cemetery, with the Bujwid and Sopot Streets and the Odra River embankment as its boundaries, 3. cultivated fields situated at a distance of $16 \mathrm{~km}$ from Wroclaw and about $2.5 \mathrm{~km}$ from any village buildings.

The Szczytnicki Park contains a wide variety of vegetation, including groups of trees and bushes and numerous grassy glades. In addition to native vegetation there are also occasional exotic species. The trees include: Quercus robur, Acer tataricum, Ulmus laevis, Taxus baccata, Tilia cordata, Acer platanoides, Robinia pseudoacacia, Aesculus hippocastanum, Fagus silvatica, Larix decidua, Crataegus monogyna, Betula verrucosa, Pinus strobus and Sorbus intermedia (planted). Species in the undergrowth include: Sambucus nigra, Hedera helix, Cornus mas and a considerable admixture of Acer platanoides.

The vegetation of the cemetery consists mainly of the following trees: Tilia cordata, Populus italica, Aesculus hippocastanum, Betula verrucosa, exotic coniferous trees, Spirea ulmifolia, Fraxinus excelsior, Fagus silvatica, Salix elegantissima, Robinia pseudoacacia, Acer platanoides, Taxus baccata, Acer pseudoplatanus, Tilia platyphyllos, Quercus robur, Padus avium. The bushes include Symphoricarpos racemosus, Prunus machale, Biota orientalis and Surmia splendida (exotic).

Among the fields of rape, wheat and fodder mixtures, where the mice were caught, there was a spinney composed of the following bushes: Prunus spinosa, Ro:a canina and Crataegus sp.

\section{MATERIAL AND METHODS}

T'he studies were carried out in two seasons: spring - end of April until June 20 th and autumn - from mid-September to November 5 th. The mice were caught in the fields by means of live-traps arranged in trapping lines, which functioned for about one week on the given site, and were then transferred to a different place. The traps were arranged in lines every $15 \mathrm{~m}$. In the park and cemetery the traps were set out at random on account of the mosaic character of the vegetation. 
A total of 597 representatives of Apodemus agrarius (Pallas, 1771) were caught, 326 of which were males and 271 females. The mice were killed by severing the spinal cord, and were then weighed, measured and dissected to determine reproductive activity and to excise the heart, kidneys, liver and skeletal muscles. The age of the animals was defined by means of analysis of eye lens dry weight (Adamczewska-Andrzejewska, 1973). The prepared organs were stored at a temperature of $-20^{\circ} \mathrm{C}$. Tissue homogenates made with two volumes of cold $0.1 \mathrm{M}$ phosphate buffer with $\mathrm{pH} 7.5$, were centrifuged for 30 minutes at $12,000 \times \mathrm{g}$ at $4^{\circ} \mathrm{C}$. LDH activity was determined by King's method (1965), taking as a unit of enzymatic activity the amount of $\mu \mathrm{mol}$ reacted pyruvate for 1 minute under test conditions. The results are expressed in the units/g of tissue.

On account of the relatively small number of mice caught in the cemetery and park these animals have been treated jointly as one urban population - the park (P). The previous analysis of the material collected did not reveal any significant differences, either morphometrical or in the level of the enzyme examined, between the mice in these two ecosystems. An additional argument justifying combination of the material was the similar composition of the vegetation in the two study areas and the fact that the cemetery was situated not far from Szczytnicki Park. The results obtained were analyzed statistically, mean values compared by means of the $t$-Student test for independent groups, with confidence level $\leqslant 0.05$.

\section{RESULTS}

\subsection{Description of Populations of Apodemus agrarius}

\subsubsection{Age Structure}

Three age classes were distinguished, applying them to generations of animals born during different periods of seasonal reproduction. Young individuals caught in June were divided as follows: class I - mice born in early spring (from $1-3$ months old), class II - mice from 4-6 months old in June, Class III — the oldest mice - old adults over 6 months old.

Mice caught in October were also divided into three age classes: class I - mice of the autumn generation ( $1-2$ months old), class II - mice of the summer generation ( $3-5$ months old) and class III - mice born before the winter or born in winter and spring (over 6 months old).

The pattern of age structure in spring differed in the two populations (Fig. 1). The percentage of the youngest mice, i.e. born in spring (with the exception of 1980) was greater in the park than in the fields. These differences were not so great in any of the other age classes in any season. It can be seen from Table 1 that the urban population was always younger in spring than the field population, although these differences were not statistically significant. 

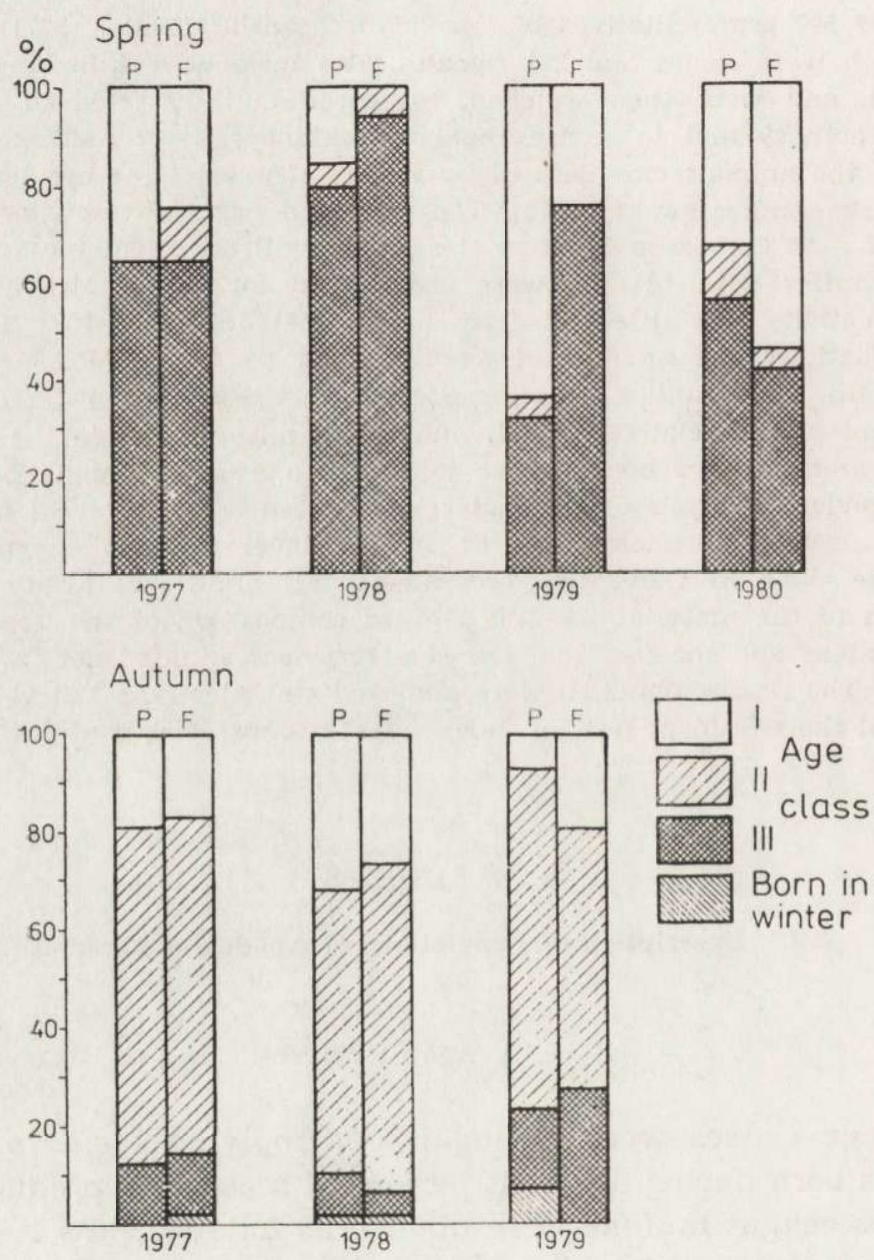

Fig. 1. Comparison of the age structure of A. agrarius populations from park (P) and field $(\mathrm{F})$.

Table 1

Average age of individuals in the examined populations, $p>0.05$.

\begin{tabular}{|c|c|c|c|c|c|}
\hline Season & Year & $\mathrm{N}$ & Park $_{\overline{\mathrm{x}} \pm \text { S.D. }}$ & $\mathrm{N}$ & $\begin{array}{l}\text { Field } \\
\qquad \bar{x} \pm \text { S.D. }\end{array}$ \\
\hline Spring & $\begin{array}{l}1977 \\
1978 \\
1979 \\
1980\end{array}$ & $\begin{array}{l}14 \\
19 \\
22 \\
39\end{array}$ & $\begin{array}{l}6.3 \pm 3.49 \\
7.6 \pm 2.85 \\
4.9 \pm 3.63 \\
6.0 \pm 3.60\end{array}$ & $\begin{array}{l}36 \\
31 \\
18 \\
24\end{array}$ & $\begin{array}{l}7.5 \pm 3.58 \\
8.9 \pm 1.87 \\
6.4 \pm 3.44 \\
6.3 \pm 3.84\end{array}$ \\
\hline Autumn & $\begin{array}{l}1977 \\
1978 \\
1979\end{array}$ & $\begin{array}{l}57 \\
47 \\
27\end{array}$ & $\begin{array}{l}4.0 \pm 1.47 \\
5.0 \pm 3.22 \\
4.4 \pm 1.62\end{array}$ & $\begin{array}{r}172 \\
90 \\
15\end{array}$ & $\begin{array}{l}3.7 \pm 1.42 \\
3.4 \pm 1.41 \\
4.4 \pm 1.72\end{array}$ \\
\hline
\end{tabular}




\subsubsection{Sex Structure}

Analysis of sex ratio showed that males predominated in both populations in spring, and in the urban population also during the autumn period, except for 1978 (Table 2), although these differences are statistically significant only in certain years.

Table 2

Percentage ratio of males in A. agrarius populations.

\begin{tabular}{|c|c|c|c|c|c|}
\hline \multirow{2}{*}{$\begin{array}{l}\text { Study } \\
\text { area }\end{array}$} & \multirow[b]{2}{*}{ Year } & \multicolumn{2}{|c|}{ Spring } & \multicolumn{2}{|c|}{ Autumn } \\
\hline & & $N$ & $\%$ & $\mathrm{~N}$ & $\%$ \\
\hline \multirow{5}{*}{ Park } & 1977 & 14 & 53.8 & 57 & 57.4 \\
\hline & 1978 & 19 & 68.1 & 47 & 40.6 \\
\hline & 1979 & 22 & 59.1 & 27 & $68.9^{2}$ \\
\hline & 1980 & 39 & 58.5 & - & - \\
\hline & 1977 & 36 & 50.0 & 172 & 55.1 \\
\hline \multirow[t]{2}{*}{ Field } & $\begin{array}{l}1978 \\
1979_{1}^{1}\end{array}$ & 31 & & $\begin{array}{l}90 \\
15\end{array}$ & $\begin{array}{l}40.8 \\
46.6\end{array}$ \\
\hline & 1980 & 24 & $67.7^{2}$ & & \\
\hline
\end{tabular}

1 Excluded because of the small number of caught individuals, ${ }^{2} \mathrm{p}<0.05,{ }^{3} \mathrm{p}<0.01$.

\subsubsection{Reproduction}

Assuming that certain relations may occur between sexual activity and LDH level, as in the case of Microtus arvalis (Wolańska \& Kubicz, 1981), distinction was made between: 1 - sexually immature females and 2 - sexually mature females. The latter were further divided into: gestating, lactating and with fresh placental scars. Males were divided into sexually active and inactive.

The percentage of animals in these classes differed in the two populations, which points to different intensity of reproduction processes (Fig. 2).

All groups of females occurred in spring in both the park and fields, but except for 1977, gestating females predominated in the park and females otherwise sexually active in the fields. Sexually active males were in the majority, and it was only in 1977 and 1980 that a small percentage was formed by sexually inactive males.

In autumn there was usually a higher percentage of sexually immature females in the urban population than in the fields. Sexually mature females also formed a considerable percentage, although gestating females were found among them only in 1977. Sexually active males occurred in each year, but the percentage was small, while the remainder were sexually inactive. 


\subsubsection{Body Weight}

The body weight of different individuals forms one of the characters indicating the population's living conditions. The mean body weight of
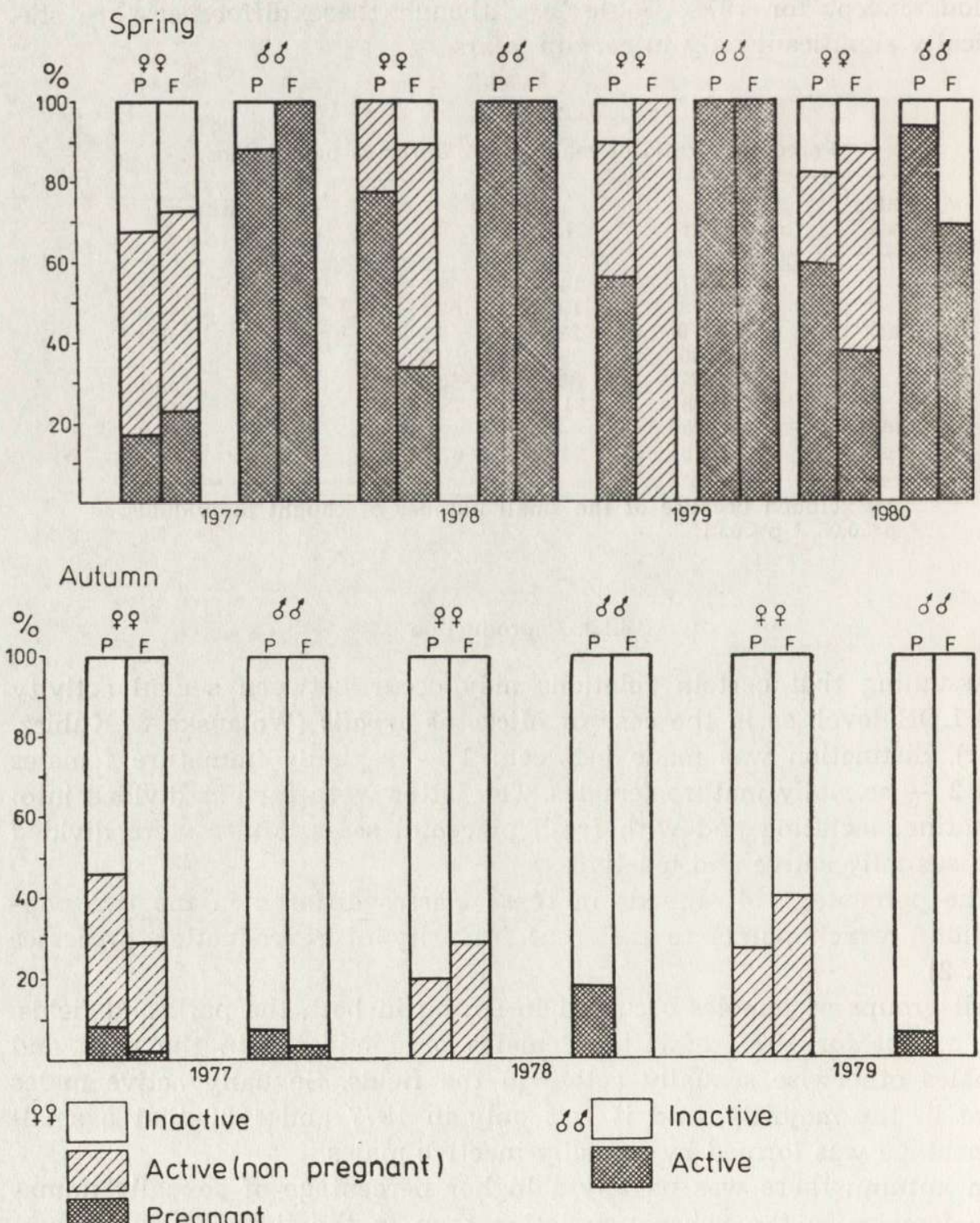

Fig. 2. Intensity of reproduction by $A$. agrarius expressed by the percentage of sexually active and inactive individuals in the populations from park (P) and field (F). 
all individuals in the two populations was very similar (Table 3) and no statistically significant differences were found $(p>0.05)$.

Table 3

Average body weight of all field mice examined (g).

\begin{tabular}{lccc}
\hline Season & Year & $\begin{array}{c}\text { Park } \\
\overline{\mathrm{x}} \pm \text { S.D. }\end{array}$ & $\begin{array}{c}\text { Field } \\
\overline{\mathrm{x}} \pm \text { S.D. }\end{array}$ \\
\hline Spring & 1977 & $22.8 \pm 7.67$ & $22.7 \pm 5.58$ \\
& 1978 & $25.2 \pm 5.15$ & $26.9 \pm 3.63$ \\
& 1979 & $22.5 \pm 5.30$ & $21.3 \pm 6.31$ \\
Autumn & 1980 & $22.4 \pm 5.07$ & $20.5 \pm 6.27$ \\
& 1977 & $16.8 \pm 4.68$ & $17.0 \pm 3.90$ \\
& 1978 & $16.8 \pm 3.89$ & $16.2 \pm 3.33$ \\
& 1979 & $17.0 \pm 4.06$ & $17.2 \pm 3.56$ \\
\hline
\end{tabular}

Table 4

Average body weight of adult males (g).

\begin{tabular}{lccc}
\hline Season & Year & $\begin{array}{c}\text { Park } \\
\overline{\mathrm{x}} \pm \text { S.D. }\end{array}$ & $\begin{array}{c}\text { Field } \\
\overline{\mathrm{x}} \pm \text { S.D. }\end{array}$ \\
\hline Spring & 1977 & $28.5 \pm 4.32$ & $25.7 \pm 4.15$ \\
& 1978 & $26.9 \pm 3.72$ & $27.7 \pm 3.07$ \\
& 1979 & $27.0 \pm 4.38$ & $27.1 \pm 3.06$ \\
& 1980 & $25.8 \pm 2.91$ & $27.0 \pm 1.73$ \\
Autumn & 1977 & $20.4 \pm 2.93$ & $19.9 \pm 3.99$ \\
& 1978 & $20.1 \pm 2.91$ & $18.0 \pm 4.43$ \\
& 1979 & $21.6 \pm 2.33$ & $18.5 \pm 1.291$ \\
\hline
\end{tabular}

${ }^{1} p<0.05$.

Adult males ( $\geqslant 5$ months) from the park were far heavier in autumn than males from the fields (Table 4). Although statistically significant differences were found only in the autumn of $1979(p<0.05)$, this is also one of the regularities occurring in the study populations of $A$. agrarius.

\subsection{LDH Activity}

4.2.1. LDH Activity Level in Different Organs

Mean LDH contents in the field mouse organs examined are given in Tables 5-7, from which it can be seen that LDH activity is on a similar level in the heart and kidneys, of 260-460 units/g of tissue, from $400-550$ in the liver, whereas the activity of this enzyme in muscles was very high and fluctuated within limits of about $750-1000$ units/g of tissue. 
Table 5

Sex differences in LDH activity (units/g of tissues).

\begin{tabular}{|c|c|c|c|c|c|}
\hline \multirow[b]{2}{*}{ Season } & \multirow[b]{2}{*}{ Organ } & \multicolumn{2}{|c|}{$\mathrm{P}$ ark } & \multicolumn{2}{|c|}{ Fie $1 \mathrm{~d}$} \\
\hline & & $\begin{array}{l}\text { Males } \\
\bar{x} \pm \text { S.D. }\end{array}$ & $\begin{array}{l}\text { Females } \\
\overline{\mathrm{x}} \pm \text { S.D. }\end{array}$ & $\begin{array}{c}\text { Males } \\
\overline{\mathbf{x}} \pm \text { S.D. }\end{array}$ & $\begin{array}{c}\text { Females } \\
\overline{\mathrm{x}} \pm \text { S.D. }\end{array}$ \\
\hline \multicolumn{6}{|l|}{ Spring } \\
\hline & $\mathrm{N}$ & 39 & 38 & 37 & 25 \\
\hline & Heart & $329.6 \pm 122.4$ & $438.1 \pm 162.3^{2}$ & $353.6 \pm 92.1$ & $367.3 \pm 111.3$ \\
\hline & Kidneys & $268.7 \pm 81.2$ & $338.5 \pm 74.0^{3}$ & $307.2 \pm 79.6$ & $363.2 \pm 79.0^{2}$ \\
\hline & Muscle & $756.1 \pm 274.4$ & $997.3 \pm 250.1^{3}$ & $854.0 \pm 238.7$ & $979.3 \pm 208.7^{1}$ \\
\hline & Liver & $409.9 \pm 141.9$ & $548.7 \pm 117.2^{3}$ & $423.6 \pm 107.4$ & $542.8 \pm 179.2^{2}$ \\
\hline \multicolumn{6}{|c|}{ Autumn } \\
\hline & $\mathrm{N}$ & 45 & 33 & 35 & 35 \\
\hline & Heart & $336.3 \pm 116.6$ & $327.3 \pm 105.0$ & $364.4 \pm 85.5$ & $353.7 \pm 119.1$ \\
\hline & Kidneys & $288.8 \pm 82.9$ & $286.8 \pm 61.9$ & $284.2 \pm 62.9$ & $296.1 \pm 113.8$ \\
\hline & Muscle & $824.9 \pm 230.8$ & $918.8 \pm 167.2^{1}$ & $905.3 \pm 290.4$ & $846.0 \pm 233.7$ \\
\hline & Liver & $396.3 \pm 122.2$ & $416.5 \pm 117.2$ & $423.8 \pm 132.4$ & $369.2 \pm 98.9$ \\
\hline
\end{tabular}

${ }^{1} p<0.05,{ }^{2} p<0.01,{ }^{3}<0.001$.

Table 6

Seasonal differences in LDH activity (units/g of tissues).

\begin{tabular}{|c|c|c|c|c|c|}
\hline & \multirow[b]{2}{*}{ Organ } & \multicolumn{2}{|c|}{ Males } & \multicolumn{2}{|c|}{ Females } \\
\hline & & $\begin{array}{l}\text { Spring } \\
\overline{\mathbf{x}} \pm \text { S.D. }\end{array}$ & $\begin{array}{l}\text { Autumn } \\
\overline{\mathbf{x}} \pm \text { S.D. }\end{array}$ & $\begin{array}{l}\text { Spring } \\
\overline{\mathbf{x}} \pm \text { S.D. }\end{array}$ & $\begin{array}{l}\text { Autumn } \\
\overline{\mathbf{x}} \pm \text { S.D. }\end{array}$ \\
\hline \multicolumn{6}{|l|}{ Park } \\
\hline & $\mathrm{N}$ & 39 & 45 & 38 & 33 \\
\hline & Heart & $329.6 \pm 122.4$ & $336.3 \pm 116.3$ & $438.1 \pm 162.4$ & $327.3 \pm 105.0^{2}$ \\
\hline & Kidneys & $268.7 \pm 81.2$ & $288.8 \pm 82.9$ & $338.5 \pm 74.0$ & $286.8 \pm 61.9^{2}$ \\
\hline & Muscle & $756.1 \pm 274.4$ & $824.9 \pm 230.8$ & $997.3 \pm 250.1$ & $918.8 \pm 167.2$ \\
\hline & Liver & $409.9 \pm 141.9$ & $396.3 \pm 122.2$ & $548.7 \pm 117.2$ & $416.5 \pm 117.2^{8}$ \\
\hline \multicolumn{6}{|c|}{ Field } \\
\hline & $N$ & 37 & 35 & 25 & 35 \\
\hline & Heart & $353.6 \pm 92.1$ & $364.4 \pm 85.5$ & $367.3 \pm 111.3$ & $353.7 \pm 119.1$ \\
\hline & Kidneys & $307.2 \pm 79.6$ & $284.2 \pm 62.9$ & $363.2 \pm 79.0$ & $296.1 \pm 113.8^{1}$ \\
\hline & Muscle & $854.0 \pm 328.7$ & $905.3 \pm 290.4$ & $979.3 \pm 208.7$ & $846.0 \pm 233.7^{1}$ \\
\hline & Liver & $423.6 \pm 107.4$ & $423.8 \pm 132.4$ & $542.8 \pm 179.2$ & $369.2 \pm 98.9^{3}$ \\
\hline
\end{tabular}

${ }^{1} p<0.05,{ }^{2} p<0.01,{ }^{3} p<0.001$.

Examination was made of the relations between LDH level in different organs and body weight, sexual activity, age and season. It was found that the activity of this enzyme is correlated with the above parameters, chiefly during autumn in females from the urban population and males from the field population. In spring the sexual activity of females in the park is correlated with LDH in the muscles $r=0.3648$ $(p<0.05)$ and with LDH in the liver $-r=0.3789(p<0.05)$, whereas in autumn body weight is correlated with $\mathrm{LDH}$ in the heart, $r=5171$ 
$(p<0.01)$, with LDH in the kidneys $r=0.3917(p<0.05)$ and with LDH in the muscles, $r=0.5670(p<0.01)$ but age is correlated with LDH in the muscles only, $r=4515(p<0.01)$.

Table 7

Differences in LDH activity between examined populations (units/g of tissues).

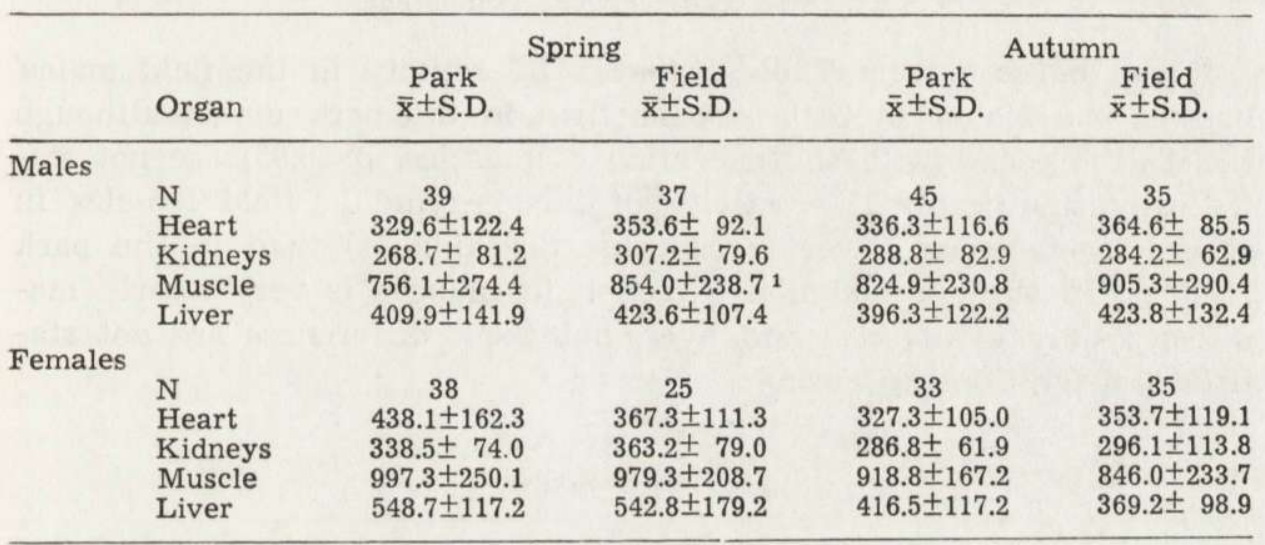

${ }^{1} p<0.05$.

No relation between LDH level and the above parameters was found for males in the park or females from the fields. A strong correlation was found in males from the fields in spring between LDH in the muscles and body weight, $r=0.4473(p<0.01)$, sexual activity $r=0.4262$ $(p<0.01)$ and age, $r=0.4378(p<0.01)$, whereas in autumn LDH in the heart was correlated with sexual activity $-r=0.3617(p<0.05)$ and with age, $r=0.5118(p<0.01)$, but $\mathrm{LDH}$ in the kidneys was correlated with age only, $r=0.5118(p<0.05)$.

\subsubsection{Differences between LDH Activity in Males and Females}

It can be seen from Table 5 that it was only in spring that LDH level was higher in females than in males in all the organs examined. In mice living in the urban park differences in $\mathrm{LDH}$ level between males and females were more clearly expressed and appeared in all four organs examined, while in muscles they were manifested even in autumn.

Further analyses were made separately for males and females.

\subsubsection{Relation between LDH Activity and Season}

It is clear from Table 6 that LDH activity in the various organs of males is not subject to any great seasonal variations. In autumn it is maintained on a level similar to that in spring, in both the urban and 
field population. Unlike males, LDH activity in females in both populations depends to a considerable degree on the season. In spring the level of this enzyme in the organs examined was higher than in autumn, differences in LDH activity being most significant in the liver.

\subsubsection{Differences between Populations}

It can be seen from Table 7 that LDH activity in the field males' organs was higher in both seasons than in the park males, although these differences (with the exception of muscles, $p<0.05$ ) are not statistically significant. The activity of this enzyme in field females in spring is, however, lower (except for the kidneys) than in the park females. In autumn a similar direction in changes is very clearly manifested only in muscles and liver, but these differences are not statistically significant $(p>0.05)$.

\section{DISCUSSION}

The description of the Apodemus agrarius populations in the Szczytnicki Park and in cultivated fields provides confirmation of the earlier observations made by Andrzejewski et al., (1978) of the populations living in the centre of Warsaw and its surrounding districts. Population density has not been taken into consideration in the present studies, since our earlier observations of Microtus arvalis (Wolańska \& Kubicz, 1981) failed to reveal any relation between $\mathrm{LDH}$ level in these rodents and their population density. Our studies have also shown that in the Wrockaw population, in the same way as in the Warsaw population, there are greater numbers of young mice in spring than in the population outside the city limits. In both populations we found numerical the field than in the urban ecosystem. The domination of this sex in predominance of males in spring, which was considerably greater in A. agrarius was described earlier by Haitlinger (1968), Pelikán (1965) and Andrzejewski et al., (1978). In the opinion of these authors it is greater in spring as a result of the males' greater activity and consequently the greater likelihood of their being caught in traps, or as the result of sex disproportion in the population due to difference in mortality between males and females.

No data have been found in literature, apart from Andrzejewski et al., (1978) on winter reproduction of Apodemus agrarius. We found several cases of births in winter in our material, in both the urban and field population (Fig. 1).

Andrzejewski et al., (1978) also showed that the body weight of adult 
males is greater in the urban population than in other populations. The results of our studies only partly agree with this, since the body weight of adult males in the Wrocław population is greater in autumn only, but this discrepancy may be due to differences in the number of individuals examined. This phenomenon may be explained by, inter alia, differences in diet, which is richer in calories in the city parks (Babinska-Werka, 1981). It has also been shown that plant food predominated over animal food in the stomachs of mice in suburban areas, whereas food of animal origin formed a considerable proportion of the diet of mice in urban park areas (Babińska-Werka \& Garbarczyk, 1981). A change in diet also affects enzymatic activity and may be the main cause of certain differences in LDH activity. Direct comparison of LDH level in animals from the urban and field populations did not reveal statistically significant differences, except in the case of muscles $-p<0.05$, but distinct intrapopulation differences were shown to exist between males and females which were particularly clearly manifested in the urban population. Greater and statistically significant LDH activity was found in females in spring than in males, whereas in the field population these differences were smaller, although also statistically significant. It is unlikely that this was related with the reproductive activity of females, since LDH activity was the same in females in both the urban and field population (Table 7). Seasonal differences in enzymatic activity, which were also statistically significant, intensified in the urban population.

Irrespective of differences in enzymatic activity, $\mathrm{LDH}$ activity was observed to be lower in the muscles of males in the urban population than in the field population, which may have been due to the lesser activity of males (moving about over smaller distances in the isolated habitat of the park).

Examination of LDH activity in the organs of A. agrarius from natural populations showed beyond doubt that the level of this enzyme in the given organ depends on sex, age and season of the year, the degree of this dependence being conditioned by habitat factors.

The results of our studies showed that the A. agrarius population in intensively urbanized areas differs in respect of age structure, body weight, sex structure and also intensity of reproduction processes from populations living at a distance from urban habitats. Although such differences were frequently statistically non-significant, they nevertheless indicate the direction of changes taking place due to the influence of different habitat factors.

In addition the urban population is characterized by more intensive intrapopulation differences, expressed in LDH level in females and 
males, and also at different seasons of the year. It was thus established that adaptational changes are reflected in both population structures and in the metabolism of Apodemus agrarius.

\section{REFERENCES}

1. Adamczewska-Andrzejewska K., 1973: Growth variation and age criteria in Apodemus agrarius (Pallas, 1771). Acta theriol., 18: 353-394.

2. Andrzejewski R., Babińska-Werka J., Gliwicz .J. \& Goszczyński J., 1978: Synurbization processes in population of Apodemus agrarius. I. Characteristics of population in urbanization gradient. Acta theriol., 23: 341-358.

3. Babińska-Werka J., 1981: Food of Apodemus agrarius (Pallas, 1771) in different types of urban green areas. Acta theriol., 26: 285-299.

4. Babińska-Werka .J. \& Garbarczyk H., 1981: Animal components of the diet of the striped field mouse under urban conditions. Acta theriol., 26: 301-318.

5. Haitlinger R. \& Korzeniowski A., 1962: Badania ekologiczne drobnych ssaków na wybranym terenie $w$ okolicy Wrocławia. Acta Univ. Wratisl., Prace zool., 1: $35-54$.

6. King J., 1965: Practical clinical enzymology. Van Nostrand: $1-85$. London.

7. Pelikán J., 1965: Reproduction, populations structure and elimination of males in Apodemus agrarius (Pall.). Zool. Listy, 14: 317-332.

8. Sikorski M. D., 1982: Craniometric variation of Apodemus agrarius (Pallas, 1771) in urban green areas. Acta theriol., 27: $71-81$.

9. Wolańska L. \& Kubicz A., 1981: Changes in the activity of lactate dehydrogenase and acid phosphatase in Microtus arvalis (Pall.) population in response to some ecological factors. Pol. ecol. Stud., 7: 245-256.

Accepted, September 11, 1985.

Ludmiła WOLAŃSKA i Aleksandra KUBICZ

CHARAKTERYSTYKA POPULACJI I AKTYWNOSCI DEHYDROGENAZY MLECZANOWEJ (LDH) APODEMUS AGRARIUS Z EKOSYSTEMOW MIEJSKICH I POL UPRAWNYCH

Streszczenie

Badania prowadzono od wiosny 1977 do wiosny $1980 \mathrm{r}$. Objęto nimi trzy ekosystemy: 1) część Parku Szczytnickiego, 2) cmentarz Sw. Wawrzyńca (we Wrocławiu), 3) pola uprawne położone poza obrębem miasta. Myszy odławiano w następujących seriach: koniec kwietnia do 20 czerwca oraz od połowy września do 5 listopada.

Prześledzono i porównano ze sobą struktury: wiekową, wagową, płciową oraz rozród w populacji miejskiej i polnej $A$. agrarius, w okresie wiosny i jesieni. Oznaczono poziom aktywności LDH w sercu, nerkach, mięśniach szkieletowych oraz w wątrobie. Obliczono korelacje między aktywnością badanego enzymu a strukturami populacyjnymi. Porównano aktywność LDH między samcami a samicami 
w obrębie każdej populacji, a także wśród samców i samic w obu sezonach. Ponadto porównano poziom LDH między populacjami.

Wykazano, że w populacji miejskiej było zawsze więcej młodych osobników, niż w populacji polnej, że ciężar ciała dorosłych samców (5 miesięcy) z parku był większy (tylko w jesieni), niż samców z pola. Jakkolwiek nie były to różnice statystycznie istotne, z wyjątkiem ciężaru ciała samców w jesieni 1979 r., to wskazywały na ten sam kierunek zmian zachodzących $w$ populacji $A$. agrarius. Stwierdzono w obu populacjach, że w okresie wiosny występuje liczebna dominacja samców. Była ona znacznie większa na polu niż w parku, w którym zaznaczała się również w jesieni. Były to różnice statystycznie istotne. Ponadto wykazano między badanymi populacjami różnice $\mathrm{w}$ intensywności procesów reprodukcji (Fig. 2).

Najwyższą aktywność LDH stwierdzono w mięśniach, najniższą w sercu i nerkach. Wykazano, że aktywność LDH jest skorelowana w różnym stopniu z ciężarem ciała, aktywnością płciową oraz wiekiem myszy polnych. Zależność tą stwierdzono tylko $\mathrm{u}$ samic $\mathrm{z}$ populacji miejskiej oraz $\mathrm{u}$ samców $\mathrm{z}$ populacji polnej. Wykazano także, że aktywność LDH samic była wiosną istotnie wyższa niż u samców. Sezonowe różnice w aktywności enzymatycznej ujawniły się tylko $\mathrm{u}$ samic, u których wiosną aktywność LDH była wyższa niż jesienią. Porównanie poziomu LDH u osobników z populacji miejskiej i polnej nie ujawniło statystycznie istotnych różnic.

Wykazano, że poziom enzymu w danym organie zależy od płci, wieku i pory roku, przy czym stopień tej zależności uwarunkowany jest czynnikami środowiskowymi.

Stwierdzono, że zmiany adaptacyjne do warunków życia w środowisku miejskim odzwierciedlają się zarówno w strukturach populacyjnych jak i metabolizmie Apodemus agrarius. 